Mayara G. Beltrão, Anderson Feijó, Anna Carolina F. Albuquerque, Getúlio L. Freitas and Fabiana Lopes Rocha*

\title{
Recording of relict ocelot (Leopardus pardalis) and South American coati (Nasua nasua) populations in the biodiversity hotspot Pernambuco Endemism Center, Northern Atlantic Forest, Brazil
}

https://doi.org/10.1515/mammalia-2017-0094

Received July 20, 2017; accepted July 10, 2018; previously published online August 29, 2018

Abstract: The northern portion of the Atlantic Forest, namely Pernambuco Endemism Center (PEC), faces an extreme level of forest loss, with only $2 \%$ of its original forest remaining. In the PEC, mesocarnivores are the only remaining carnivores and, among them, the ocelot and South American coati present a poorly known or even ignored distribution. Our goal is to provide an overview of the current distribution and conservation status of both species in the PEC through camera trap survey, review of published scientific literature and a search for voucher specimens in mammal collections. Our data confirm the presence of the ocelot and the South America coati in the PEC. The ocelots were mainly recorded in fragments smaller than $12 \mathrm{~km}^{2}$, suggesting they might access the monoculture matrix and anthropogenic areas. The few recent records of coatis suggest a worse scenario, predicting an imminent local extinction. The PEC has witnessed a historical continued deforestation, which has reduced the remaining fragments and contributed to the accentuated decline of both species populations. Nevertheless, these

\footnotetext{
*Corresponding author: Fabiana Lopes Rocha, Laboratório de Mamíferos, Departamento de Sistemática e Ecologia, Centro de Ciências Exatas e da Natureza (CCEN), Universidade Federal da Paraíba, Cidade Universitária s/n, João Pessoa, PB 58051900, Brazil; and Programa de Pós-graduação em Ecologia e Monitoramento Ambiental, Centro de Ciências Aplicadas e Educação, Universidade Federal da Paraíba, Rio Tinto, PB 58.297-000, Brazil, e-mail: lopesrocha.fabiana@gmail.com. https://orcid.org/0000-0003-0819-6290

Mayara G. Beltrão and Anna Carolina F. Albuquerque: Laboratório de Mamíferos, Departamento de Sistemática e Ecologia, Centro de Ciências Exatas e da Natureza (CCEN), Universidade Federal da Paraíba, Cidade Universitária s/n, João Pessoa, PB 58051-900, Brazil; and Programa de Pós-Graduação em Ciências Biológicas (Zoologia), Departamento de Sistemática e Ecologia, CCEN, Universidade Federal da Paraíba, João Pessoa, PB 58051-900, Brazil Anderson Feijó: Key Laboratory of Zoological Systematics and Evolution, Institute of Zoology, Chinese Academy of Science, Beichen West Road, Chaoyang District, 100101 Beijing, China Getúlio L. Freitas: ICMBio, Reserva Biológica Guaribas, REBIO Guaribas, PB 071, km 01, Mamanguape, PB 58.280-000, Brazil
}

Atlantic Forest remnants are paramount to supporting relict populations of mesocarnivores in the PEC, and their maintenance and connectivity should be a conservation priority.

Keywords: camera trap; local extinction; mesocarnivores; ocelot; South American coati.

\section{Introduction}

The Atlantic Forest is one of the most diverse, endemic and threatened biomes of the world, qualifying it as a biodiversity hotspot (Myers et al. 2000). Most of its 8-12\% remnants are reduced to secondary fragments (Fundação SOS Mata Atlântica/INPE 2015). This biome spans over $3000 \mathrm{~km}$ from $30^{\circ} \mathrm{S}$ to $7^{\circ} \mathrm{S}$ and has been regionalized in up to eight biogeographical sub-regions (Ribeiro et al. 2009). Its northernmost portion, namely the Pernambuco Endemism Center (hereafter PEC), shows the highest level of forest loss, with only $2 \%$ of its original forest remaining (Silva and Tabarelli 2000, Tabarelli et al. 2003, ToledoLima et al. 2014). Deforestation was mainly caused by historical continued sugarcane plantations over the last 500 years since the colonization of Brazil (Coimbra-Filho and Câmara 1996, Vivo 1997). Its fauna is characterized by endemic taxa and well-known defaunation, marked by local extinction of the large-sized species (Vivo 1997, Silva Jr. and Mendes Pontes 2008, Canale et al. 2012).

Responses to the effects of landscape changes vary among carnivorous species according to the landscape configuration, habitat use, resource acquisition, niche breadth and movement capacity (Virgós et al. 2002, Swihart et al. 2003, Regolin et al. 2017). Yet, on a landscape scale, carnivorous richness and species composition can be affected by forest cover and other fragmentation metrics (Regolin et al. 2017). In the PEC, mesocarnivores are the only remaining carnivores, whereas the large felids, such as the jaguar Panthera onca (Linnaeus, 1758) and the cougar Puma concolor (Linnaeus, 1771), are regionally extinct along with other large mammals [the brown brocket Mazama gouazoubira (G. Fischer [von Waldheim], 1814), the giant anteater Myrmecophaga tridactyla Linnaeus, 1758, the collared peccary 
Pecari tajacu, (Linnaeus, 1758) the white-lipped peccary Tayassu pecari (Link, 1795) and the lowland tapir Tapirus terrestris (Linnaeus, 1758)] (Feijó and Langguth 2013).

In the Atlantic Forest, the ocelot [Leopardus pardalis (Linnaeus, 1758)] and the South American coati [Nasua nasua (Linnaeus, 1766)] are among the most common mesocarnivores (Rocha-Mendes et al. 2010, Kasper et al. 2015). The coati is an omnivorous, diurnal and conspicuous species, which lives in large groups and emits loud vocalizations that are easily identified by lay people (Gompper and Decker 1998). The ocelot is the major midsized predator of seed dispersers (Moreno et al. 2006, Roemer et al. 2009) and the largest living predator of the PEC (Feijó and Langguth 2013). Both species occur in a variety of habitats, including tropical-humid forests, savannas, mangroves and deciduous and dry forests (Murray and Gardner 1997, Gompper and Decker 1998). Because of their conspicuity, high abundance in Atlantic Forest areas and complementary ecologic habitats, they could be used as a primary proxy to assess the suitability of the remaining PEC forest fragments for mesocarnivores.

Both species are widely distributed in the Neotropics (Gompper and Decker 1998, Paviolo et al. 2015, Emmons and Helgen 2016); yet, their presences in the PEC are poorly known or even ignored (Paviolo et al. 2015, Emmons and Helgen 2016). Records for ocelots and South American coati from the PEC are rare (Feijó and Langguth 2013) and most of the few existing ones are not based on direct evidences, such as voucher specimens, photographs or capture (e.g. Mendes Pontes et al. 2016). Therefore, our aim is to perform an overview of the current distribution of ocelots and coati in the PEC through three complementary approaches: (1) systematic camera trap survey in Atlantic Forest remnants within the PEC, (2) systematic review of published scientific literature and (3) search for voucher specimens assigned to the PEC in mammal collections. Moreover, we discuss the distribution and conservation implications for each species and the main threats for mesocarnivores in the region.

\section{Materials and methods}

\section{Camera-trap sampling}

We installed camera-trap grids in three Atlantic Forest protected areas in the Paraiba state from November 2015 to

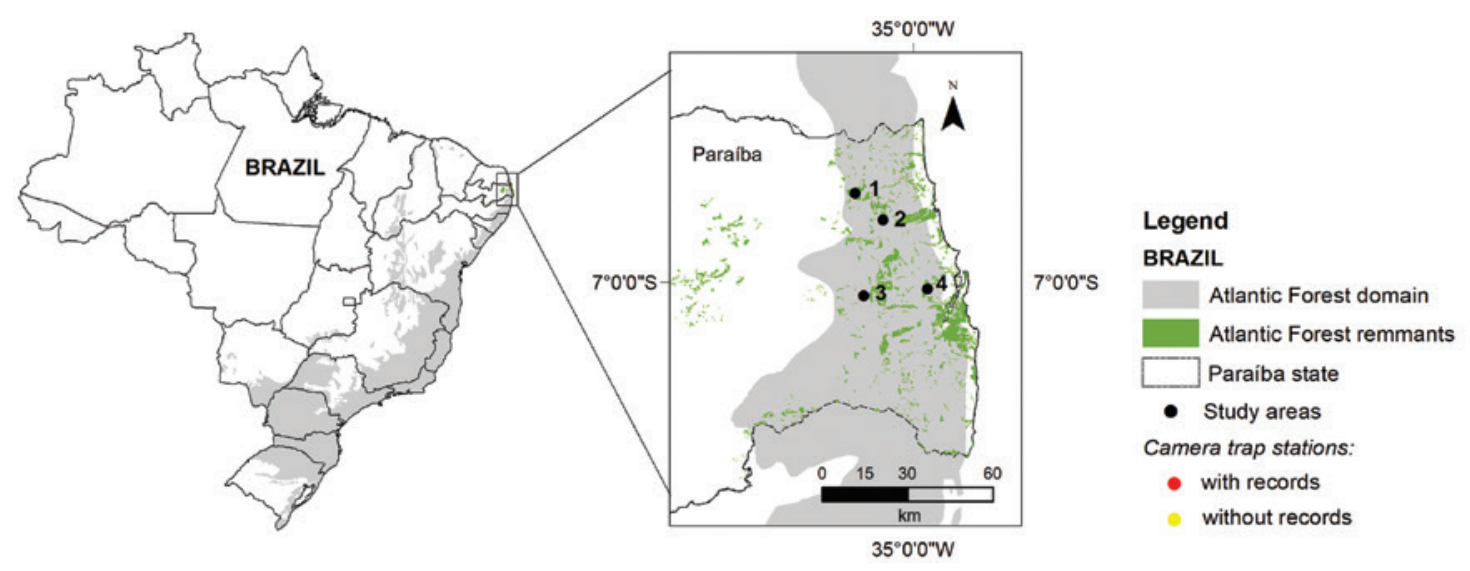

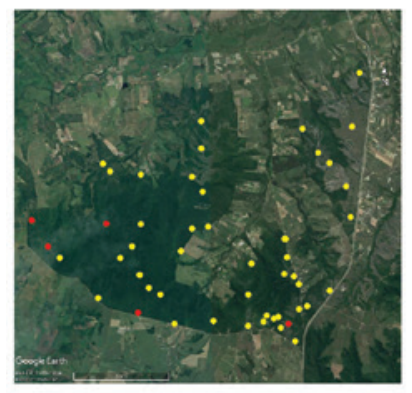

1 - Rebio Guaribas Sema II

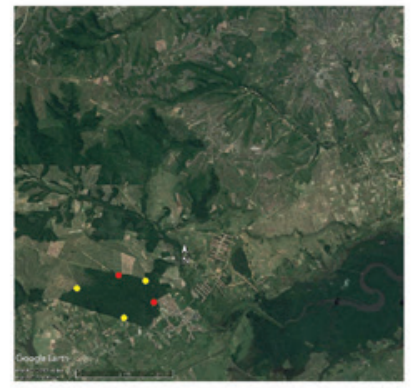

2 - Rebio Guaribas Sema III

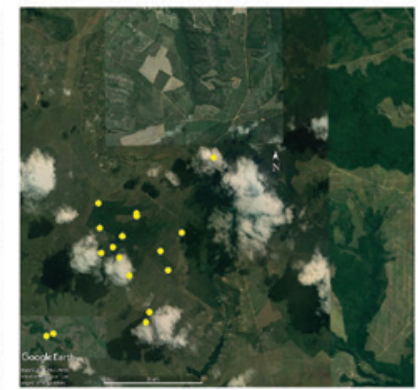

3 - RPPN Pacatuba

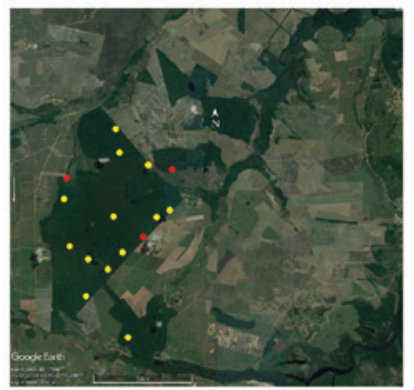

4 - RPPN Gargaú

Figure 1: Location of the Guaribas Biological Reserve (Sema II e III), Private Reserve of Natural Heritage Pacatuba and Engenho Gargaú with all camera-trap station locations (with and without records). 
April 2017. The first protected area, the Guaribas Biological Reserve (Rebio Guaribas), consists of three fragments covering 4051.62 ha of which we sampled two, called SEMA II $\left(6^{\circ} 43^{\prime} 47.90^{\prime \prime} \mathrm{S} / 35^{\circ} 10^{\prime} 57.33^{\prime \prime} \mathrm{W}\right)$ and SEMA III $\left(6^{\circ} 48^{\prime} 10.25^{\prime \prime} \mathrm{S} / 3\right.$ $\left.5^{\circ} 5^{\prime} 48.45^{\prime \prime} \mathrm{W}\right)$. The second is the Private Reserve of Natural Heritage (RPPN) Fazenda Pacatuba $\left(7^{\circ} 2^{\prime} 22.97^{\prime \prime} \mathrm{S} / 35^{\circ} 9^{\prime} 30.8\right.$ $\left.5^{\prime \prime} \mathrm{W}\right)$, which has an area of 266.53 ha of continuous forest. The third is the RPPN Engenho Gargaú $\left(7^{\circ} 0^{\prime} 56.41^{\prime \prime} \mathrm{S} / 34^{\circ} 5\right.$ $7^{\prime} 0.29^{\prime \prime}$ W) which has an area of 1058.62 ha covered with forest in different successional stages interspersed by flooded and open areas.

Camera traps [models: Trophy Cam HD - 119537, Trophy Cam - 119436, Trophy Cam - 119446 and Trophy Cam Brown - 119435 Bushnell $^{\circledast}$ equipment manufactured by Bushnell Corporation, Overland Park, KS, USA] were set at $1 \mathrm{~km}$ interval (Figure 1) and about $50 \mathrm{~cm}$ above ground. They were baited with sardines, fruits and/or commercial raccoon or wildcat lure [Hawbaker’s ${ }^{\circledR}$ (S Stanley Hawbaker \& Sons, Fort Loudon, PA, USA)]. Camera traps operated continuously ( $24 \mathrm{~h}$ per day), with a $1 \mathrm{~min}$ interval between $30 \mathrm{~s}$ videos when triggered, during 30 days per station. Trap stations were checked every 15 days to refresh bait and change batteries, if necessary. In addition, 22 camera trap stations were randomly arranged at a minimum of $500 \mathrm{~m}$ from each other, in fragments for initial exploration before the establishment of our camera trap grid. We considered only the first video of the same species from the same trapping station as an independent record for analytical purposes (Srbek-Araujo and Chiarello 2013). Camera trap capture success was estimated based on the number of independent records divided by the number of camera trap nights and multiplied by 100 (Dillon 2005), including all camera-trap stations. The project had permission from the Chico Mendes Institute for Biological Conservation - ICMBio (Instituto Chico Mendes para Conservação da Biodiversidade - SISBIO license number 43641-3) to conduct this study, in accordance to Brazilian regulations.

\section{Literature review}

For the systematic literature review, we obtained data on the occurrence of Leopardus pardalis and Nasua nasua from PEC through Scopus (www.scopus.com) and Web of Science - WOS (www.webofknowledge.com) databases. We used the keywords "Leopardus pardalis", "Nasua nasua", "medium mammals", "carnivorans", "Carnivora”, "carnivorous", "Paraíba”, "Pernambuco", "Pernambuco Endemism Center", "Atlantic Forest” and
"Northeastern" and "Brazil" with different combinations and without date restriction, both in English and Portuguese. Additional references were searched through citation tracking of the original articles and through a search of Brazilian carnivore researcher's curriculum Lattes (lattes.cnpq.br).

\section{Museum records}

We visited six mammalian collections between 2011 and 2016 to search for voucher specimens of ocelots and coati assigned to PEC: Coleção de Mamíferos da Universidade Federal da Paraiba, João Pessoa, Brazil (UFPB), Coleção de Mamíferos da Universidade Federal de Pernambuco, Recife, Brazil (UFPE), Museu Nacional da Universidade Federal do Rio de Janeiro, Rio de Janeiro, Brazil (MN), Museu de Zoologia da Universidade de São Paulo, São Paulo, Brazil (MZUSP), American Museum of Natural History, New York, NY, USA (AMNH) and Field Museum of Natural History, Chicago, IL, USA (FMNH).

\section{Results}

We obtained a total of 14 ocelot and 13 South American coati records assigned to the PEC through the combination of the three methods (camera traps survey, literature review and mammal collection search) (Table 1). The records were distributed among 17 different localities, of which three were from Alagoas, seven from Pernambuco, six from Paraíba and one from Rio Grande do Norte states (Figures 2 and 3).

The total grid sampling had 69 camera-trap stations covering an area of 5376.77 ha, with a total sampling effort of 1813 trap days, considering all camera-trap stations. We obtained seven ocelots' video records in different cameratrap stations (independent records) from Rebio Guaribas and three from RPPN Engenho Gargaú, resulting in a total ocelot capture success of $0.5 \%$. There were no ocelot camera trap records in RPPN Fazenda Pacatuba, neither records of the South American coati in any of the sampled areas.

Our literature search retrieved 145 articles from WOS and 148 from Scopus. Only four mentioned Leopardus pardalis from the PEC: Cruz et al. (2002), Mendes Pontes et al. (2016), Silva Jr. and Mendes-Pontes (2008) and Marinho et al. (2017). The first three studies also reported records for the Nasua nasua from the PEC as well as Feijó and Langguth (2013). However, we did not 


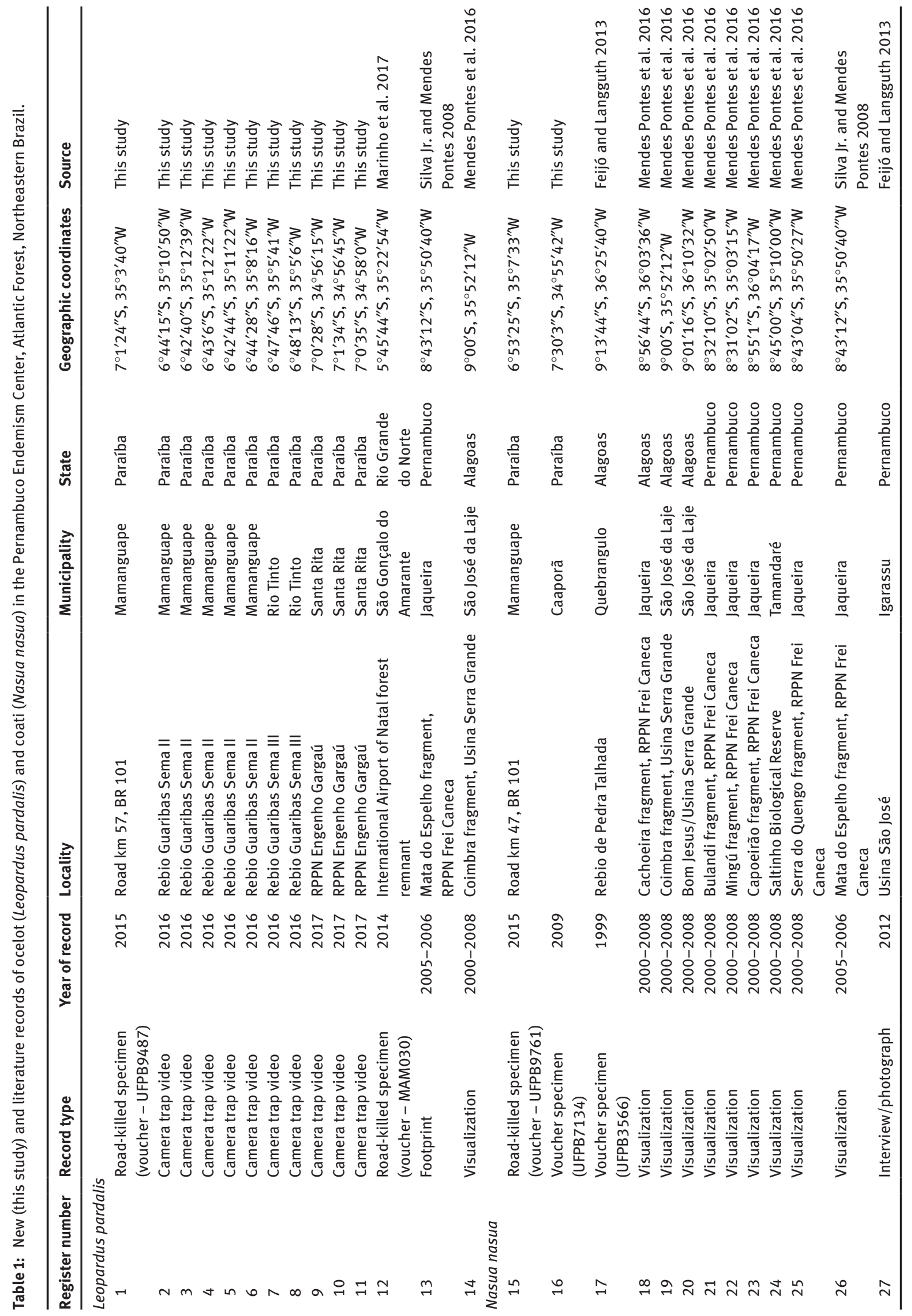




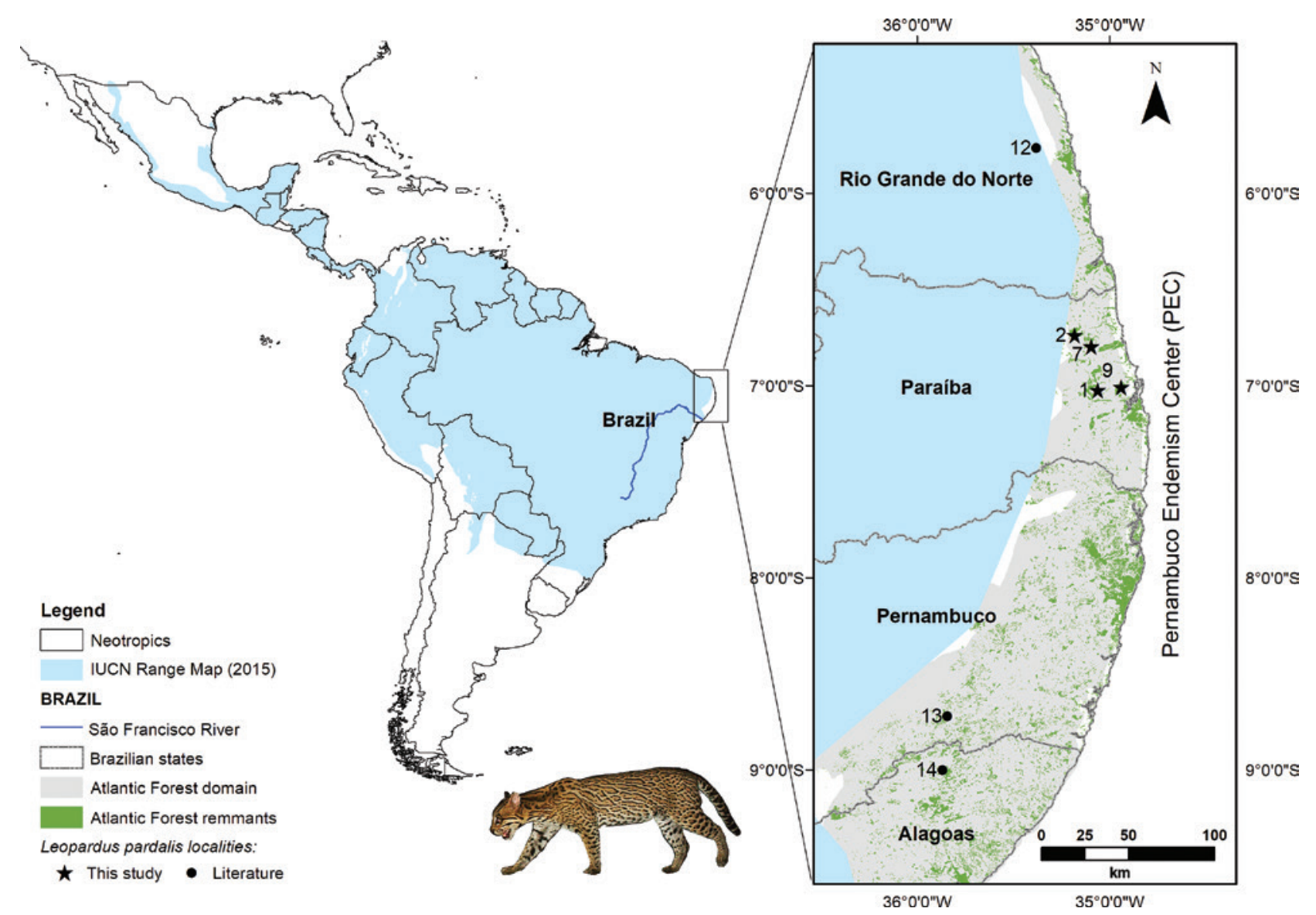

Figure 2: Locality records of ocelot (Leopardus pardalis) within the Pernambuco Endemism Center, Northeastern Brazil. The numbers correspond to the records description in Table 1.

include in our dataset the records from Cruz et al. (2002) because they were based on unreliable sources such as interviews considering that Leopardus species can be easily misidentified by local people. Nevertheless, we included one interview record from Feijó and Langguth (2013), because it was given by a biologist and also provided a photographic record of the species (A. Feijó, personal communication).

Regarding the mammal collection assessment, we found only three voucher specimens that could be assigned to the PEC at the mammal collection of the UFPB. One, an adult male of Leopardus pardalis (UFPB 9487) was road killed in December 2014 in the BR101 highway, km 57, city of Santa Rita, Paraíba, Brazil ( $7^{\circ} 1^{\prime} 24^{\prime \prime}$ S, 35 $\left.5^{\circ} 3^{\prime} 40^{\prime \prime} \mathrm{W}\right)$. On the same road ( $\mathrm{km} \mathrm{47)}$, on February 2015, one adult male of Nasua nasua (UFPB 9761) was found road killed near the city of Mamanguape ( $\left.6^{\circ} 53^{\prime} 25^{\prime \prime} \mathrm{S}, 35^{\circ} 7^{\prime} 33^{\prime \prime} \mathrm{W}\right)$, and represents the northernmost record of the species in the PEC, extending the known distribution of coati around $123 \mathrm{~km}$ northward. In addition, there is a coati skull (UFPB7134) collected in 2009 in the city of Caaporã, south of Paraiba. The surrounding landscape of all these areas is dominated by a sugarcane matrix with sparse and discontinuous small remnants of Atlantic Forest.

\section{Discussion}

Our assembled data confirm the current presence of the ocelot and the South American coati in the PEC. Although these species are among the most common mediumsized carnivores in other Atlantic Forest areas (RochaMendes et al. 2010, Kasper et al. 2015), we obtained only a few records for both species, even with multi-complementary approaches. The scarcity of records for ocelots and coatis could be either due to an ongoing local extinction process, which may be a result of low population density or even a sink population or be explained yet by incipient field effort in the region. The current scenario seems to be different for each species and should be carefully evaluated.

Our 2 year camera trap survey was the first mediumterm systematic study focused on the medium-sized terrestrial mammals of PEC and the first to uncover relict 


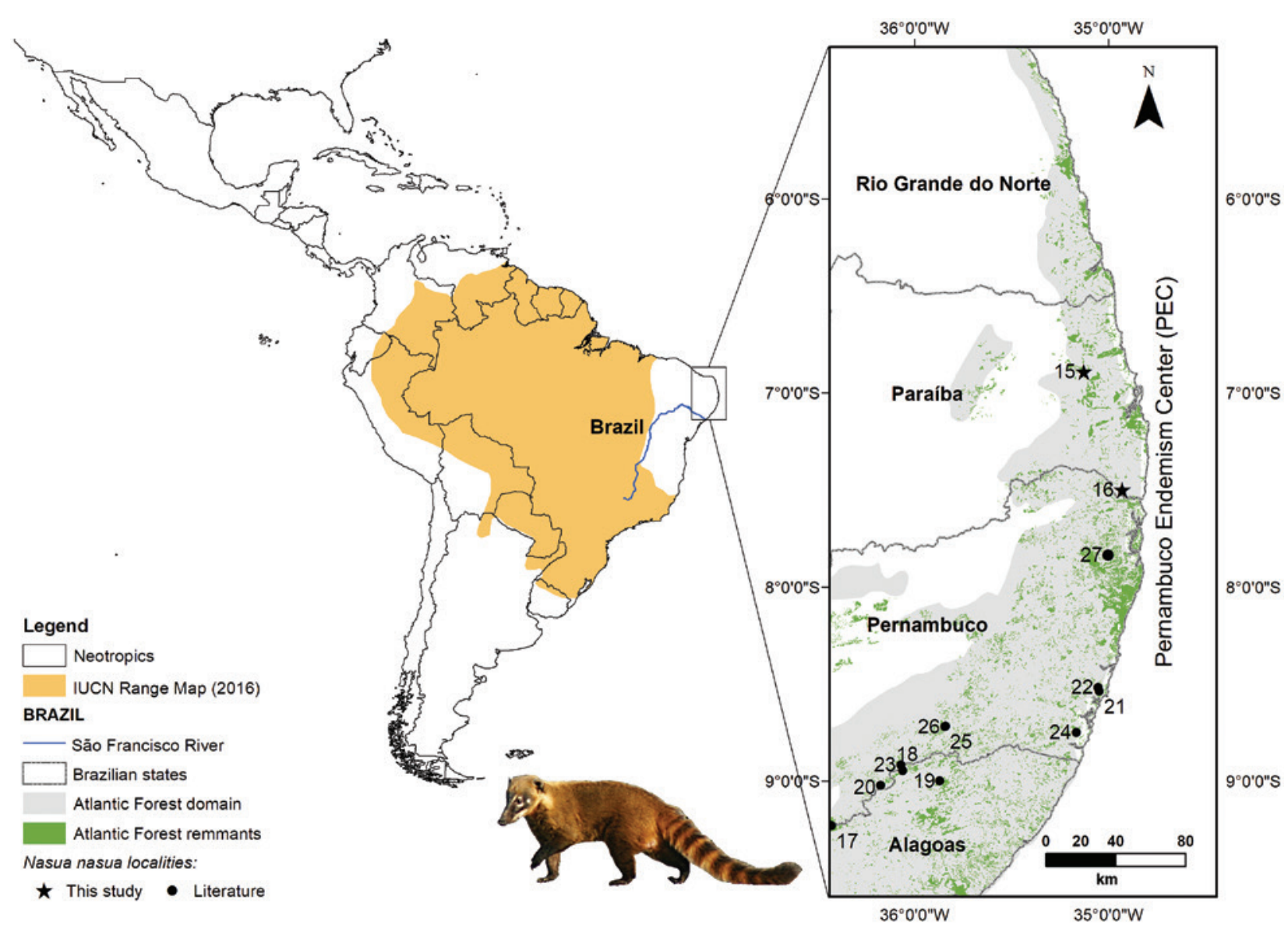

Figure 3: Locality records of the South America coati (Nasua nasua) within the Pernambuco Endemism Center, Northeastern Brazil. The numbers correspond to the description of records in Table 1.

populations of ocelots from the Paraiba state, filling a distributional gap (Figure 1). A similar scenario is expected for other areas of the PEC, given that the ocelot is not an easy species to detect without a focused survey and, to the best of our knowledge, we are the only research group with a systematic survey using camera traps in the northern portion of the Atlantic Forest. Therefore, increasing the field sampling effort might reveal other relict populations of Leopardus pardalis along the Atlantic Forest remnants in the PEC.

Our ocelot capture rate is low (0.5\%) compared to other areas of the Atlantic Forest. Goulart et al. (2009), Srbek-Araujo and Chiarello (2013) and Kasper et al. (2015), studying ocelot populations from southern and southeastern Brazil, reported a capture rate of $0.9 \%, 0.9 \%$ and $13.1 \%$, respectively. Therefore, our results indicate that the ocelot's remnant populations might occur in a very low abundance. Ocelots require wide home ranges that can reach up to $7.5 \mathrm{~km}^{2}$ in the southern portion of the Brazilian Atlantic Forest (Goulart et al. 2009) and above $13.4 \mathrm{~km}^{2}$ in Belize and in the Atlantic Forest of Argentina (Di Bitetti et al. 2006, Dillon and Kelly 2007). The animals were recorded in isolated and small fragments, mainly less than $12 \mathrm{~km}^{2}$. Hence, it is expected that the ocelots from the PEC constantly access the monoculture matrix and anthropogenic areas, making them more exposed and vulnerable to hunting pressure (Robinson 1996, Turner and Corlett 1996, Cullen Jr. et al. 2000). Thus, even with the possible addition of records with increasing field efforts, in terms of conservation, the situation of these remaining populations seems to be critical.

The actual scenario seems to be worse for the South American coati. Most recent records are mainly restricted to Pernambuco and dated from about 10 years ago.

From the earliest zoological studies in northeastern Brazil there were records of Nasua nasua, beginning in the XVII century by George Marcgrave who was the first naturalist to record fauna in this region (Marcgrave 1648). After this period, the PEC region was again scientifically explored between 1859 and 1861, in a specific expedition in the Paraíba, Pernambuco and Ceará states where the presence of coati was reported (Lagos 1862). These records 
demonstrate the occurrence of that specie for the PEC in very different periods, suggesting that the presence of that specie was not uncommon when compared to the scenario that we verified through the recent data.

Thus, the scarcity of recent records seems to be mainly explained by an imminent local extinction emphasized by the absence of recent records of this species throughout our survey. We suggest that this ongoing local extinction may be the result of low population density or even a sink population, strongly influenced by the historical exploitation of the natural resources in this region. It is possible to verify that there is an aggregation of records in the southern region of the PEC, on the boundary between of the of Alagoas and Pernambuco states (Figure 3), suggesting that the remnants of Alagoas may be refuge for the sourcepopulations and preclude the extinction with the immigrants overcoming the emigrants (Akçakaya et al. 2007). In addition, the absence of visualization by researchers over several years of fieldwork in the area, even within primate-focused studies, which show an overlap of habitat and activity period with the coatis (e.g. Fialho and Gonçalves 2008, Montenegro 2011) supports our hypothesis of an imminent local extinction for the coati instead of insufficient field effort.

The northern portion of the Atlantic Forest has experienced continued deforestation over the last 500 years since the early stage of the colonization of Brazil. Since the 1970s, a large and rapid expansion of sugarcane plantation has further reduced the remaining PEC' fragments to only $2 \%$ of its original area (Tabarelli et al. 2003, Toledo-Lima et al. 2014), which contributed to the accentuated decline of the ocelot and coati populations, as well as that of other carnivores in the region (Mendes Pontes et al. 2016). Such a defaunation scenario (Silva Jr. and Mendes Pontes 2008, Canale et al. 2012) may also be related to the historical and still common practice of hunting in the region (Souza and Alves 2014). According to Alves et al. (2016) hunting of Leopardus pardalis is mainly related to conflicts with local human population. The habitat loss and the increasing hunting of other species causes a reduction of potential prey of the ocelot, leading it to expand its home range closer to human settlements and be hunted as a result. On the other hand, the South American coati is not among the preferred game among hunters in northeastern region Brazil (Alves et al. 2016). However, loss of forested habitat and time of isolation of the fragments are putative threats that affect this species (Michalski and Peres 2005, Emmons and Helgen 2016). According to Michalski and Peres (2007), coatis are sensitive to small-sized fragments because breeding populations require forest patches of at least 80 ha.
In addition, contracted diseases from domestic animals, such as distemper, can decimate rapidly populations of Nasua nasua (Beisiegel and Campos 2013).

Our data reinforce the need to increase efforts to shed light on the ecological parameters of the remaining ocelot and coati populations. Studies of diet, home range size, connectivity of forest fragments and adaptability to the sugarcane plantation may bring crucial information about their requirements that future conservation plans in this highly fragmented and threatened ecoregion may be based on. Also, multi-complementary surveys should be encouraged as an initial effort to uncover other relict carnivore populations within the PEC. Howsoever, the importance of remnant fragments to support the threatened fauna of mesocarnivores in the PEC is paramount, their maintenance and connectivity should be a conservation priority.

Acknowledgments: We are indebted to Vitor Rademaker and Helder Farias Pereira de Araújo for lending us the camera traps that made this work possible. We also thank Ramon Lima and the trainees of the Laboratório de Mamíferos da UFPB for their assistance during field work. We are thankful to the managers of the Reserva Biológica Guaribas and Usina Japungu for the logistical support offered during the fieldwork. This work was supported by the Coordenação de Aperfeiçoamento de Pessoal de Nível Superior (CAPES) with MSc scholarships for ACFA, PhD for MGB and PNPD for FLR and by Rufford Foundation (grant project no. 20950-1, Funder Id: 10.13039/100007463).

\section{References}

Akçakaya, H.R., G. Mills and C.P. Doncaster. 2007. The role of metapopulations in conservation. In: (D.W. Macdonald and K. Service, eds.) Key topics in conservation biology. Blackwell Publishing, New Jersey. pp. 64-84.

Alves, R.R.N., A. Feijó, R.R.D. Barboza, W.M.S. Souto, H. FernandesFerreira, P. Cordeiro-Estrela and A. Langguth. 2016. Game mammals of the Caatinga biome. Ethnobiol. Conserv. 5: 1-51.

Beisiegel, B.M. and C.B. Campos. 2013. Avaliação do risco de extinção do quati (Nasua nasua, Linnaeus 1766) no Brasil. Biodivers. Bras. 3: 269-276.

Canale, G.R., C.A. Peres, C.E. Guidorizzi, C.A.F. Gatto and M.C.M. Kierulff. 2012. Pervasive defaunation of forest remnants in a tropical biodiversity hotspot. PLoS One 7:1-9.

Coimbra-Filho, A.F. and I.G. Câmara. 1996. Os limites originais do bioma Floresta Atlântica na região nordeste do Brasil. Fundação Brasileira para Conservação da Natureza, Rio de Janeiro. pp. 86.

Cruz, M.A.O.M., M.C.C. Cabral, L.A.M. Silva and M.L.C.B. Campelo. 2002. Diversidade da mastofauna no estado de Pernambuco. 
In: (M. Tabarelli and J.M.C. Silva, eds.) Diagnóstico da biodiversidade de Pernambuco. Editora Massangana, Recife. pp. 557-579.

Cullen Jr., L., R.E. Bodmer and C.V. Pádua. 2000. Effects of hunting in habitat fragments of the Atlantic forests, Brazil. Biol. Conserv. 95: 49-56.

Di Bitetti, M.S., A. Paviolo and C. Angelo. 2006. Density, habitat use and activity patterns of ocelots (Leopardus pardalis) in the Atlantic Forest of Misiones, Argentina. J. Zool. 270: 153-163.

Dillon, A. 2005. Ocelot density and home range in Belize, Central America: camera-trapping and radio telemetry. M.Sc. thesis. Virginia Polytechnic Institute and State University, Virginia, USA.

Dillon, A. and M.J. Kelly. 2007. Ocelot Leopardus pardalis in Belize: the impact of trap spacing and distance moved on density estimates. Oryx 41: 469-477.

Emmons, L. and K. Helgen. 2016. Nasua nasua. The IUCN Red List of Threatened Species 2016: e.T41684A45216227. Available from http://dx.doi.org/10.2305/IUCN.UK.2016-1.RLTS. T41684A45216227.en [accessed 16 June 2017].

Feijó, A. and A. Langguth. 2013. Mamíferos de médio e grande porte do Nordeste do Brasil: distribuição e taxonomia, com descrição de novas espécies. Rev. Nord. Biol. 22: 3-225.

Fialho, M.S. and G.F. Gonçalves. 2008. Primates Da Rppn Gargaú, Paraíba, Brasil. Neotrop. Primates 15: 50-54.

Fundação SOS Mata Atlântica/INPE. 2015. Atlas dos remanescentes florestais da Floresta Atlântica e ecossistemas associados no período de 2013-2014. Fundação SOS Floresta Atlântica, São Paulo. pp. 60.

Gompper, M.E. and D.M. Decker. 1998. Nasua nasua. Mamm. Species. 580: 1-9.

Goulart, F.V.B., M.E. Graipel, M.A. Tortato, I.R. Ghizoni Jr., L.G.R. Oliveira-Santos and N.C. Cáceres. 2009. Ecology of the ocelot (Leopardus pardalis) in the Atlantic Forest of Southern Brazil. Neotrop. Biol. Conserv. 4: 137-143.

Kasper, C.B., F.D. Mazim, J.B.G. Soares and T.G. Oliveira. 2015. Density estimates and conservation of Leopardus pardalis southernmost population of the Atlantic Forest. Iheringia 105: 367-371.

Lagos, M.F. 1862. Relatório da Seção Zoológica. In: (BRASIL eds.) Trabalhos da Commissão Scientifica de Exploração. Typographia Universal Laemmert, Rio de Janeiro. pp. 145-170.

Marcgrave, G. 1648. Historiae Naturalis Brasiliae. Haack and Elzevier, Amsterdam. 442 p.

Marinho, P.H., A. Feijó, S.A. Gavilan, E.O. Moura and E.M. Venticinque. 2017. First records of Ocelot Leopardus pardalis (Linnaeus, 1758) (Carnivora: Felidae) from Rio Grande do Norte, northeastern Brazil. Check List 13: 1-7.

Mendes Pontes, A.R., A.C.M. Beltrão, I.C. Normande, A. Malta, A.P. Silva Júnior and A.M.M. Santos. 2016. Mass extinction and the disappearance of unknown mammal species: scenario and perspectives of a biodiversity hotspot's hotspot. PLoS One 11: $1-26$.

Michalski, F. and C.A. Peres. 2005. Anthropogenic determinants of primate and carnivore local extinctions in a fragmented forest landscape of southern Amazonia. Conserv. Biol. 124: 383-396.

Michalski, F. and C.A. Peres. 2007. Disturbance-mediated mammal persistence and abundance-area relationships in Amazonian forest fragments. Conserv. Biol. 21: 1626-1640.
Montenegro, M.M.V. 2011. Ecologia de Cebus flavius (Schreber, 1774) em remanescentes de Mata Atlântica no estado da Paraíba. PhD thesis, Universidade de São Paulo, Piracicaba, SP.

Murray, J.L. and G.L. Gardner. 1997. Leopardus pardalis. Mamm. Species 548: 1-10.

Myers, N., R.A. Mittermeier, C.G. Mittermeier, G.A.B. Fonseca and J. Kent. 2000. Biodiversity hotpots for conservation priorities. Nature 403: 853-858.

Paviolo, A., P. Crawshaw, A. Caso, T. de Oliveira, C.A. Lopez-Gonzalez, M. Kelly, C. De Angelo and E. Payan. 2015. Leopardus pardalis. (errata version published in 2016) The IUCN Red List of Threatened Species 2015: e.T11509A97212355. Available from http://dx.doi.org/10.2305/IUCN.UK.2015-4.RLTS. T11509A50653476.en. [accessed 16 June 2017].

Regolin, A.L., J.J. Cherem, M.E. Graipel, J.A. Bogoni, J.W. Ribeiro, M.H. Vancine, M.A. Tortato, L.G. Oliveira-Santos, F.M. Fantacini, M.R. Luiz, P.V. de Castilho, M.C. Ribeiro and N.C. Cáceres. 2017. Forest cover influences occurrence of mammalian carnivores within Brazilian Atlantic Forest. J. Mammal. 98: 1721-1731.

Ribeiro, M.C., J.P. Metzger, A.C. Martensen, F.J. Ponzoni and M.M. Hirota. 2009. The Brazilian Atlantic Forest: how much is left, and how is the remaining forest distributed? Implications for conservation. Biol. Conserv. 142: 1141-1153.

Robinson, J.G. 1996. Hunting wildlife in forest patches: an ephemeral resource. In: (J. Schellas and R. Greenberg, eds.) Forest patches in tropical landscapes. Island Press, Washington. pp. 111-130.

Rocha-Mendes, F., S.B. Mikich, J. Quadros and W.A. Pedro. 2010. Feeding ecology of carnivores (Mammalia, Carnivora) in Atlantic Forest remnants, southern Brazil. Biota Neotrop. 10: 21-30.

Roemer, G.W., M.E. Gompper and V. Valkenburgh. 2009. The ecological role of the mammalian mesocarnivore. BioScience 59: 165-173.

Silva Jr., A.P. and A.R. Mendes Pontes. 2008. The effect of a megafragmentation process on large mammal assemblages in the highly-threatened Pernambuco Endemism Centre, north-eastern Brazil. Biodivers. Conserv. 17: 1455-1464.

Silva, J.M.C. and M. Tabarelli. 2000. Tree species impoverishment and the future of the Atlantic forest of Northeastern Brazil. Nature 404: 72-74.

Souza, J.B. and R.R.N. Alves. 2014. Hunting and wildlife use in an Atlantic Forest remnant of northeastern Brazil. Trop. Conserv. Sci. 7: 145-160.

Srbek-Araujo, A.C. and A.G. Chiarello. 2013. Influence of cameratrap sampling design on mammal species capture rates and community structures in southeastern Brazil. Biota Neotrop. 13: $51-62$

Swihart, R.K., T.C. Atwood, J.R. Goheen, D.M. Scheiman, K.E. Munroe and T.M. Gehring. 2003. Patch occupancy of North American mammals: is patchiness in the eye of the beholder? J. Biogeogr. 30: 1259-1279.

Tabarelli, M., J.A. Siqueira-Filho and A. Santos. 2003. A Floresta Atlântica ao norte do rio São Francisco. In: (K.C. Pôrto, J.S. Almeida-Cortez and M. Tabarelli, eds.) Diversidade Biológica e Conservação da Floresta Atlântica ao Norte do Rio São Francisco. Ministério do Meio Ambiente, Brasília. pp. 25-40.

Toledo-Lima, G.S., P. Macario, R.M. Lyra-Neves, B.P. Teixeira, L.A.F. Lima, G.O.S. Sugliano and W.R. Telino-Júnior. 2014. Richness, composition and trophic groups of an avian community in the 
Pernambuco Endemism Centre, Alagoas, Brazil. An. Acad. Bras. Ciênc. 86: 1207-1219.

Turner, I.M. and R.T. Corlett. 1996. The conservation value of small, isolated fragments of lowland tropical rain forest. Trends Ecol. Evol. 11: 330-333.

Virgós, E., J.L. Tellería and T. Santos. 2002. A comparison on the response to forest fragmentation by medium-sized Iberian carnivores in central Spain. Biodivers. Conserv. 11: 1063-1079.

Vivo, M. de. 1997. A mastofauna da Floresta Atlântica: padrões biogeográficos e implicações conservacionistas. Anais da Reunião Especial da SBPC: Floresta Atlântica: Diversidade Biológica e Sócio-Econômica, Blumenau, Santa Catarina. pp. 60-63. 